$\begin{array}{ll} & \text { Etnográfica } \\ \text { etnográfica } & \text { Revista do Centro em Rede de Investigação em }\end{array}$

Antropologia

vol. 20 (3) | 2016

Vol. 20 (3)

\title{
The origin and evolution of language
}

A origem e a evolução da linguagem

\section{António Bracinha Vieira}

\section{(c)enEdition \\ Journals}

\section{Electronic version}

URL: https://journals.openedition.org/etnografica/4745

DOI: $10.4000 /$ etnografica. 4745

ISSN: 2182-2891

\section{Publisher}

Centro em Rede de Investigação em Antropologia

\section{Printed version}

Date of publication: 1 October 2016

Number of pages: 658

ISSN: 0873-6561

Electronic reference

António Bracinha Vieira, "The origin and evolution of language ", Etnográfica [Online], vol. 20 (3) | 2016,

Online since 28 November 2016, connection on 11 February 2022. URL: http://

journals.openedition.org/etnografica/4745 ; DOI: https://doi.org/10.4000/etnografica.4745

\section{(c) (i) (9)}

Etnográfica is licensed under a Creative Commons Attribution-NonCommercial 4.0 International License. 


\title{
The origin and evolution of language
}

\section{António Bracinha Vieira}

\begin{abstract}
This brief note introduces the hypothesis that language evolution was associated with tool use in the Palaeolithic and contributed to brain development. Cláudia Sousa shared a strong interest in chimpanzee vocalisations and how they could contribute to our understanding of human speech.
\end{abstract}

KEYWORDS: language, evolution, tools, brain, lithic industries.

A origem e a evolução da linguagem • Esta breve nota introduz a hipótese de a evolução da linguagem associada à utilização de ferramentas no Paleolítico ter contribuído para o desenvolvimento cerebral. Cláudia Sousa partilhava um forte interesse nas vocalizações de chimpanzés e como poderiam contribuir para o nosso entendimento da evolução da fala humana.

PALAVRAS-CHAVE: linguagem, evolução, ferramentas, cérebro, indústrias líticas.

VIEIRA, António Bracinha (vieyrantonio@hotmail.com) - Centre for Philosophy of Sciences (CFC-UL), Universidade de Lisboa, Portugal.

\section{A THEORY IS PRESENTED ON THE ORIGIN AND EVOLUTION OF LANGUAGE} by means of natural selection, based on the hypothesis of grammatical and syntactic equivalents in the use of Palaeolithic tools: as well as verbal flexion, core flaking implies to remember and anticipate; likewise, the effects of tools have adverbial, nominal and adjectival equivalents.

Despite parturition accidents induced by newborn brain and skull growth, selection favoured language and the new social biology it brought about. With the anticipation of birth, the newborn became immature and more dependent on mother care and cultural norms.

Deep changes in the vocal organs and linguistic brain structure exclude a single macro-mutation for language: under the action of FOX P2 genes, the articulatory larynx evolved from some prehuman hominoid vocalizing larynx.

We postulate the evolution of language by evolutionary levels, parallel to the modules of lithic industries. The cortex where tool work projects being close to the motor area of speech and to "mirror neurons", the hypothesis seems plausible that the brain wiring underlying tool-use was preadapted (exaptation) to language. 